\title{
The Politics of Protest in Newspaper Campaigns: \\ Dissent, Populism and the Rhetoric of Authenticity
}

Jen Birks, British Politics 6(2): 128-154

\begin{abstract}
Newspaper campaigns embody newspaper' most emphatic claims to speak for 'the people', and as such are generally regarded as populist. However, they can be oppositional, engaging in dissent of one sort or another, and often assume a certain amount of political engagement with that dissent on the part of the audience. This article examines the potential of newspaper camapigns to facilitate the political engagement of citizens through the politics of protest. It draws on qualitative analysis of seven campaigns that ran in the Scottish press between 2000 and 2005, and semistructured interviews with relevant journalists. The distinction between legitimate protest and manipulative populism is made in terms of: (a) the rhetoric and strategies of political representation, participation and influence and (b) the construction of political legitimacy in terms of the public interest and the moral authority of the 'victim'. It is argued that populist impulses dominate, driving a tendency to use discourses of emotional authenticity and offence to legitimise demands for a plebiscitary response to popular of 'victim' preference and to close down controversy and debate, with the principal objective marketing the newspaper as an influential community champion.
\end{abstract}

Keywords: populism; press; campaigning; protest; personal authenticity; moral legitimacy

\section{Introduction}

Newspaper campaigns embody newspapers' most emphatic claims to speak for 'the people', and as such are generally regarded as populist (Aldridge, 2003, Conboy, 2002). Whilst campaigns with political aims are often oppositional, engaging in dissent of one sort or another, and assume a certain amount of political engagement with that dissent on the part of the audience, critics question the democratic legitimacy of newspapers' rhetorical appeals to public opinion. This article examines the potential of newspaper campaigns to facilitate the political engagement of citizens through the politics of protest.

Protest in the 1970s and 1980s was associated with marginalised progressive challenges to what the media framed as a dominant conservative consensus (Hollingsworth, 1986). However, alongside 
social and political gains made by civil rights and equality movements, political protest too has become mainstream, extending beyond left-wing agenda to become a "cacophonous field" which has "seemingly expanded the parameters of the 'political' in contemporary civil society" (Cottle, 2008: 867), and has therefore been embraced in some circumstances by news media. Indeed, in a Demos study, Milne (2005) accused the media of no longer manufacturing hegemonic consent, but instead manufacturing dissent. The implication is that protests supported, amplified, or initiated by news media are inauthentic and contrived, an argument echoed by government ministers (Blair, 2007, Branigan, 2005) who protest that the press are now anti-establishment and set on undermining the political system by inciting protest with populist rhetoric.

Of course, politicians are bound to object to criticism and opposition to policies for which they feel they are already mandated through representative democracy. Yet it is broadly agreed that protest is a central principle of liberal democracy (Joyce, 2002) and for some it is becoming increasingly important as a way of "vitalising moribund parliamentary democracies" (Cottle, 2008: 853) by providing a platform for the voices of those who feel marginalised by the political system (perhaps protecting the system by providing a safety valve), and by engaging the audience with a less paternalistic, more demotic and emotional presentation of political issues (Blumler and Kavanagh, 1999, Temple, 2006). Again, however, the press is also blamed for causing this disconnect from conventional politics, especially by eroding trust in representatives through fixating on scandal (Lloyd, 2004), and by 'dumbing down' through focusing on human interest angles over the 'public interest' (Franklin, 1997). However, many scholars have recognised the value of a broader notion of the public sphere that includes emotional engagement with social and political issues (Higgins, 2008, Temple, 2006).

Furthermore, dissent is not necessarily against the state, incumbent government (whether conservative or 'liberal') or political establishment ${ }^{1}$. As well as rejection of the views of the powerful, dissent can also be understood as the "rejection of views that most people hold" (Sunstein, 2003). Whilst Sunstein (2003: 7) equates this principally with sociopathic and "nutty" views, it also includes challenging received wisdom and popular prejudice in ways that may aspire to popular engagement without being reactionary. 


\section{Campaign Journalism}

Temple (2005) categorises newspaper campaigns in terms of those with a consumerist focus, those with political aims, and those that engage with the formal political process; whilst he focuses on the last of these, it is the second category that is examined here. Journalists define political newspaper campaigns rather broadly. Firstly, in rather circular logic, as a series of articles explicitly labelled as a campaign, branded with a title (often in the form of a slogan, such as 'Hands Off Yorkhill', or an objective, such as 'Sarah's Law') and preferably a logo: so something that is sold and marketed as a campaign. Secondly, as the pursuit of a political goal, the achievement of which the newspaper can claim as a victory: so as a particularly focused form of protest advocacy. Other criteria are related more to effectiveness than definition, but it is broadly agreed that the objective should have the potential for broad public support, and the tabloids tend to look for potential to get the readers involved in expressing that support.

The requirement for broad public support suggests that the form of dissent is likely to be against a ruling minority rather than against 'common sense', and therefore that this type of reporting has a strong inclination toward populism, reinforcing popular assumptions through an anti-establishment discourse. However, occasionally a newspaper campaign will confound expectation. In particular, there has been a series of local press campaigns against the deportation of families of asylum seekers, in the Bolton Evening News, Yorkshire Evening Post, and the Bristol Evening Post (Lupton, 2006), which would seem to contradict perceived public opinion - typically judged to be hostile to immigration and asylum. Temple (2005) argues that this sort of campaigning is most likely to occur in the local and regional press because of the diverse, mainstream audience and the greater trust invested in local newspapers, whilst Aldridge (2003) argues that local press campaigns are particularly populist for the same reasons. Both focus on the English local press, whereas this study examines the post-devolution Scottish press, which has a different relationship with notions of 'local' and 'national'. It analyses a range of campaigns that appeal to common interests and values in different ways, on issues including asylum as well as public service and law and order.

\section{Electoral disillusionment, protest and populism}

Although protest may be motivated by disillusionment with conventional political activity, that is not to say that those who engage in political protest do not vote, as Milne (2005) suggests. Research suggests far more of a correlation between the two forms of political activity, with voters using protest 
as a supplementary form to compensate for the shortcomings of conventional political activity, whilst those who are electorally disengaged are also unlikely to protest (Joyce, 2002: 40). In other words, protesters may be disillusioned with the system of representative politics, including feelings of marginalisation or exclusion, either from the political opportunity structure (in the case of outsider groups) or policy focus (in the case of many single issues), but they are not disengaged from politics. However, loss of confidence in the political system will not always lead citizens to an organised political response, but may make populist rhetoric more attractive.

The distinction between press protest as a legitimate part of pluralist liberal democracy (or as an element of participatory or deliberative democracy) and as manipulative populism will be made in terms of a) the rhetoric and strategies of political representation, participation and influence, and b) the construction of political legitimacy in terms of the public interest and the moral authority of the 'victim'.

\section{Political representation and participation}

According to Canovan (1999), populism is an intrinsic element of liberal democracy that appeals to the democratic ideal of popular sovereignty, balancing out the equally intrinsic (though popularly disparaged) pragmatics of political practice (bureaucracy, negotiation of interests, and so on). This "redemptive" political discourse seems to perform a similar function to protest in Cottle's argument above, that of revitalising representative democracy and reconnecting people with it. However, for Barr (2009), a key distinction between populism and protest is in the extent to which this claim to represent popular demand is rooted in genuine consultation and grassroots initiative, or legitimised through plebiscitary backing. Protest invites input and contribution from concerned members and seeks to have a voice in the decision-making process of the conventional political system, whilst populism rallies to a pre-determined cause and seeks a more direct influence on decisions, through a less bureaucratic (or discursive) form of accountability (Barr, 2009: 36). This is similar to Habermas' (1996) distinction between those who emerge from and constitute the public sphere, and those who appear before it to advance their own agenda.

Arguably the populist approach is merely an extension of the 'watchdog' role of the press, whereby it is assumed that the public are disengaged from politics and invest their democratic legitimacy instead in journalists as their more trusted representatives (Higgins, 2008: 35-44, Schudson, 1998, p. 136). This borrowed legitimacy can be misused for ideological or - more commonly in the highly 
commercialised local press - market-driven purposes (Bromley, 2005), using the discourse of peoplepower without actually enabling or empowering the people (Conboy, 2002, Temple, 2006), but instead to promote a brand identity that inspires loyalty and trust by establishing the newspaper as an influential political agent ${ }^{2}$ (Temple, 2005). Claims to speak on behalf of a diverse readership can also depend on the construction of a generalised 'public interest'.

\section{Political legitimacy: the public interest and personal authenticity}

In common with investigative journalism (Ettema and Glasser, 1998), newspaper campaigns have two key criteria for establishing the public interest justification for their activities - firstly, wrongdoing by individuals (and less frequently, systemic failures), preferably that can be objectively measured against formal public standards, statements, or objectives, and secondly, the less easily defined unjust impact on affected individuals. The need for the problem to rouse moral outrage at these injustices among the public, however, presumes a consensus on the 'public interest', which may be defined in terms of a Rousseauian general will, universal or liberal democratic principles, or instrumental selfinterest (Bryant, 1995). The latter could lead to the selection of only issues that affect the majority or mainstream of society, and exclude marginal groups who are most dependent on extra-parliamentary activity to get their voices heard.

However, campaigns are also run on issues that affect only a section of the population, and cannot therefore rely entirely on personal interest to engage the public, but must appeal to shared values or principles. It is possible that those campaigns could seek to advance a marginal interest or argument on the basis of its political or evidentiary merit alone, but it is more common for support to be recruited or constructed through appeals to "human universals" such as "family values", by focusing on the personal stories of those affected by issues "designed to engage reader sympathies" (Temple, 2005: 421; see also Aldridge 2003). This demands an engagement with values and emotions rather than or in addition to - 'objective' dispassionate reporting. Ettema and Glasser (1998) argue that values play a structuring role in investigative reporting, but that journalists negotiate a delicate line between being the moral conscience of the people and exerting moral authority - in terms of campaign advocacy this is the line between seeking popular support and constructing dissent through populist rhetoric. 
Canovan (1981) argued that in the political context ${ }^{3}$ populism is where leaders aim "by playing on the resonances of popular unity and distrust of faction, to ride to power on a fragile and temporary mood of popular harmony" (1981: 268). Populist campaigns therefore involve claims to speak for "the people' as one, or at least for a non-ruling (and non-organised - 'silent') majority. In asserting this moral justification, newspapers compete with political decision-makers for the legitimacy lent by 'the people'. Having no mandate, and depending instead on appeals to fairness and human universals, newspapers may define the moral legitimacy of their policy objectives in term of strength of feeling the emotional authenticity or 'ordinary people' - and demand the same of politicians.

A focus on political personalities over issues is cited as part of the 'dumbing down' thesis (Franklin, $1997)^{4}$. Arguably, the focus has long been on informing voters of pertinent personal qualities such as competence and trustworthiness (Lippmann, 1993 [1927]), but the contemporary personalisation of politics involves a greater focus on politicians' private lives and emotional authenticity (Langer, 2007). Blumler and Kavanagh argue that "politicians are likely to seek to demonstrate their 'regular guy' qualities" (1999: 224) because media abundance means the dilution of politics into cultural and human interest media genres and formats, aimed at what Higgins (2008) calls the "cultural public", with knockon effects on news media. Whilst the prioritisation of "emotional/affective responses to political problems" (Blumler and Kavanagh, 1999: 220) risks closing down political argument (and scrutiny of many areas of politics deemed too boring) in favour of sentiment, it could potentially open up politics to a greater transparency about personal conviction and how it relates to action in the political system (Corner, 2003). However, there is little agreement on the distinction between the anti-elitist demotic and the populist.

If politicians are increasingly expected to communicate in emotional terms and called upon to demonstrate empathy with those affected negatively by problems, then to an extent this simply demands that leaders are mindful of the effects of their decisions on people's lives. This could be regarded as what the Scottish moralists called "moral sentiment" (Seligman, 1995: 205), or "manners, education and cultivation which enjoin respect for the sensibilities of others" (Bryant, 1995: 143), an other-orientation that is part of private conscience and civility. As political society (including parties and parliament) mediates between civil society and the state, but is rooted in the former not the latter (Cohen and Arato, 1992: x), this is a perfectly appropriate expectation of political representatives within liberal democracy. However, this is distinct from the imposition of a specific public morality as a 
collective conscience or civic virtue, where individuals must submit to the moral expectations of the community (Bryant, 1995). In that case politicians would be expected to reflect the dominant consensus, favouring the status quo and potentially constraining progressive initiatives with aims such as protecting the liberties of minorities.

In summary, this paper will examine the sample of campaigns in terms of two aspects. Firstly, whether the campaigns perform a mobilisation function for citizens, or portray politics as remote and inaccessible to them, necessitating the mediation of their dissent by the newspaper. Secondly, how the campaigns appeal to or construct a sense of public moral outrage and political moral obligation in terms of public interest or emotional authenticity (moral sentiment or civic virtue). It is argued that populism thrives where a legitimacy gap opens up (Blumler and Kavanagh, 1999), so political reforms aimed at increasing accessibility and transparency may facilitate protest within the system rather against it. In this context, campaigns aimed at the devolved Scottish Parliament are particularly interesting.

\section{Scottish political context}

The Scottish Parliament was designed to facilitate less centralised, more consensual and accountable decision-making than at Westminster, though in practice this was compromised by the continuing influence of party politics (Arter, 2004). However, the design also included mechanisms for facilitating public and civil society access to that decision-making, but through institutional means as opposed to populism's appeals to direct democracy. Chief among these mechanisms are pre-legislative public consultation and the Petitions Committee.

Civil society associations are guaranteed pre-legislative consultation, and (until its demise in 2005) were invited to join the Scottish Civic Forum to facilitate the process (Lynch, 2001), although critics argued that, despite guidance on inclusivity and widening accessibility, well-resourced groups dominated and the system has failed to eliminate private lobbying (Lynch, 2001: 127, Schlesinger, et al., 2001). The legitimacy of consultation can be undermined if it is regarded as a cosmetic exercise, lending give an impression of transparency and public accountability to a pre-determined policy, but it is not intended to be a referendum on policy preference.

Consultation is a time-limited exercise when we provide specific opportunities for all those who wish to express their opinions on a proposed area of our work (such as identifying issues, 
developing or changing policies, testing proposals or evaluating provision) to do so in ways which will inform and enhance that work (Scottish Executive, 2004: 3)

Some consultation areas clearly require participants to offer a certain amount of expertise or specialist knowledge, but others ("identifying issues") may be based on experience of social problems and public service delivery.

The Petitions Committee considers appeals and protests submitted by citizens, and if they are found to warrant further attention passes them on to the relevant subject committee, which is obliged to respond to it in some manner (even if only discussing it and explaining why they will take no action). The process requires that petitioners have first approached their constituency MSP or one of their regional MSPs, and exhausted the avenues suggested or facilitated by them. The petitioner is invited to address the committee, and the full transcript of the meeting is then published on the parliament website. Whilst more formal and more bureaucratic than the UK government's online petition system (a collaboration between the Prime Minister's Office and voluntary organisation MySociety since 2007), the Petitions Committee is more likely to produce an effective response. There has been a record of successfully holding external public bodies such as quangos to account, but the committee has been less successful in terms of scrutinising the Scottish Executive (Lynch, 2001: 85)

Scotland also enjoys an unusually distinctive regional (quasi-national) press, which has the potential to respond to changes in the political system by empowering people to participate more directly in politics, but operates under the same (or more severe, given declining circulations) market constraints. There is therefore no guarantee that the Scottish press will be more likely to perform a mobilizing rather than populist role in protest than is the case in the British press.

\section{Case studies and method}

Due to the episodic nature of campaigning journalism, this research took the form of a multiple case study. A sample frame for the period 2000 to 2005 was compiled from the Newsbank online archive by using 'campaign and not election' as a search term, then excluding those that were fundraising, public information, or consumer campaigns. A manageable, but systematic and reasonably representative sample was identified by selecting newspaper titles as opposed to individual campaigns. The most actively campaigning title (as measured by number of articles) in each of three market segments - quality, popular and city evening newspapers - was selected. The three 
newspapers were broadsheet quality The Herald, popular tabloid the Daily Record and city tabloid the Evening Times, and in all, 542 articles were analysed across seven campaigns in these three newspapers.

\begin{tabular}{|c|c|c|c|c|c|}
\hline Newspaper & Campaign title & Objective & $\begin{array}{l}\text { Date } \\
\text { from }\end{array}$ & Date to & No. \\
\hline \multirow{5}{*}{ Daily Record } & $\begin{array}{l}\text { Keep the Clause } \\
\text { (Section 28) }\end{array}$ & $\begin{array}{l}\text { Against repeal of ban on } \\
\text { 'teaching homosexuality' }\end{array}$ & $14 / 01 / 00$ & $31 / 05 / 00$ & 41 \\
\hline & $\begin{array}{l}\text { Shop a Dealer } \\
\text { (drugs) }\end{array}$ & $\begin{array}{l}\text { Against drugs and seeking } \\
\text { tougher sentencing }\end{array}$ & $17 / 11 / 00$ & 04/05/01 & 121 \\
\hline & $\begin{array}{l}\text { Shop a Shark (loan } \\
\text { sharks) }\end{array}$ & $\begin{array}{l}\text { Seeking tighter regulation of } \\
\text { loan sharks }\end{array}$ & $10 / 01 / 02$ & $18 / 10 / 02$ & 29 \\
\hline & $\begin{array}{l}\text { Ned Culture } \\
\text { (ASBOs) }\end{array}$ & $\begin{array}{l}\text { In support of anti-social } \\
\text { behaviour legislation }\end{array}$ & 02/09/03 & $11 / 09 / 03$ & 14 \\
\hline & Airgun Ban & Seeking ban on airguns & 03/03/05 & $30 / 06 / 05$ & 57 \\
\hline The Herald & $\begin{array}{l}\text { Dungavel: } \\
\text { Scotland's Shame }\end{array}$ & $\begin{array}{l}\text { Against holding children in } \\
\text { asylum detention centres / Ay } \\
\text { family to stay in the UK }\end{array}$ & 09/01/03 & $03 / 11 / 03$ & 58 \\
\hline $\begin{array}{l}\text { Evening } \\
\text { Times }\end{array}$ & Hands off Yorkhill & $\begin{array}{l}\text { Against closure of Queen } \\
\text { Mother's maternity hospital }\end{array}$ & 09/10/03 & 01/10/04 & 222 \\
\hline
\end{tabular}

Table 1: Sample

The Daily Record was the most active during this period, which covers the tenure of three editors. Martin Clarke had taken the normally Labour-supporting tabloid to the right, aiming to expand a more mid-market audience, when he ran the 'Keep the Clause' campaign against the repeal of Section 28 (legislation that outlawed 'teaching homosexuality' in schools, also known as Clause 2A in Scottish law) early in the first term of the Scottish Parliament. Even though the bill was carried through by cross-party support, the campaign dampened the reforming spirit of the new parliament and executive (McCrone, 2002). Peter Cox ran two campaigns aimed at social ills affecting deprived areas, for tougher enforcement against drug (principally heroin) dealers and loan sharks, taking the newspaper back to its traditional working class readership. The drugs campaign involved a march and rally attended by an estimated 20,000 people. Finally, Bruce Waddell took a more cautious approach to campaigning, with a letter-writing campaign in favour of Scottish Executive proposals on anti-social behaviour, and calling for a ban on airguns following the death of a toddler. 
Glasgow's evening newspaper, the Evening Times, ran the longest and most dogged campaign, against the closure of one of Glasgow's three maternity hospitals, the Queen Mother's. The closure was necessitated by a shortage of obstetricians along with a falling birth rate, and local health board recommended the Queen Mother's because it lacked emergency care for mothers experiencing complications. The campaign focused on the hospital's link with the children's hospital on the same site in Yorkhill and its specialist neo-natal care, but falsely suggested a threat to this sister hospital. The campaign involved a petition that attracted 156,000 signatures.

The broadsheet The Herald, Scotland's best-selling quality, ran the most unusual campaign highlighting the plight of a family of Turkish Kurd asylum-seekers (the Ay family) held in Dungavel Immigration Removal Centre for a year and facing deportation. They called for the family to be granted leave to remain as recompense for their treatment, and for a halt to the detention of child asylum-seekers. Although the newspaper did not initiate any protest, it hosted debate on the topic on its letters page and gave some publicity to protests organised by civil society groups.

Newspaper texts were identified digitally from the Newsbank database, using search terms (facilitated by the newspaper practice of using a title or slogan to label campaign articles), and analysed using NVivo computer-assisted qualitative data analysis software. Computer-assisted qualitative content analysis or framing analysis uses search nodes both as 'representation' in terms of quantitative measurement, and as a 'resource' to facilitate indexing and retrieval for further qualitative analysis of meaning through structures, qualities or context. Search terms were largely identified 'in vivo' from the initial read-through to avoid imposing researcher bias, but organised under theoretically-informed parent nodes such as 'affected individuals', 'wrongdoing and blame', 'moral principle' and 'moral judgement', as well as all references to various publics (explored elsewhere).

Semi-structured interviews were also carried out with 15 key journalists and editors involved with the three campaigns. Coding again emerged predominantly from the data, this time through hand-coding by theme rather than word-searches, and was organised under parent nodes such as 'professional ideology', 'social organisation', 'ownership and commerce', 'audience' and 'publics'. Data was triangulated not through multiplicative corroboration but structural corroboration, partly because of differences between 'etic' news articles as pre-existing textual artefacts and 'emic' interview transcripts as texts produced by the data-gathering process, but principally because the data measured different 
aspects of the news-making process, the texts being the product (the 'what') of the practices described by journalists (the 'why'). The interviews allowed motivations and external pressures to be explored rather than simply speculated on from the texts (Philo, 2007). Interviews were also conducted with the three ministers whom the campaigns were intended to influence (in the offices of Justice, Social Justice / Communities, and Health), which here elucidate the negotiated strategies of political influence.

\section{Political representation and participation: redemptive rhetoric and pragmatic strategies}

This section will first examine the portrayal of the conventional political system (voting and appealing to constituency representatives), and the additional forms of access provided by the Scottish parliamentary system (pre-legislative consultation and the Petitions Committee), in contrast with the redemptive discourses of the campaign demands. Secondly, it will address the campaigns' basis in participatory or plebiscitary support. Finally, it will conclude with an examination of the newspapers' motivations for campaigning, and their credibility as mobilizing popular dissent.

Perhaps unsurprisingly, the campaigns all portrayed conventional political activity as ineffective in relation to the issues at hand. The system of constituency representation was almost universally ignored by the newspapers. Although enterprising MSPs did secure coverage of their written questions and motions to the government, this was portrayed as supporting the newspapers' efforts, and as a secondary form of representation, with practically no coverage of the resulting debate. 


\begin{tabular}{|c|c|c|}
\hline Campaign & Parliamentary action & Coverage in newspaper \\
\hline Loan sharks & $\begin{array}{l}1 \text { motion lodged in each parliament, } \\
\text { both debated }\end{array}$ & $\begin{array}{l}\text { Text of motions reported as declarative } \\
\text { support }\end{array}$ \\
\hline $\begin{array}{l}\text { Anti-social } \\
\text { behaviour }\end{array}$ & $\begin{array}{l}\text { Extensive debate on Anti-social } \\
\text { Behaviour Bill in Holyrood }\end{array}$ & No coverage of debate \\
\hline Airguns & $\begin{array}{l}1 \text { motion lodged and debated in } \\
\text { Westminster }\end{array}$ & $\begin{array}{l}\text { Only references to the campaign } \\
\text { reported }\end{array}$ \\
\hline \multirow[t]{2}{*}{ Dungavel } & $\begin{array}{l}7 \text { motions lodged in Holyrood, } 1 \\
\text { debated }\end{array}$ & $\begin{array}{l}\text { Only outcome of the debated motion } \\
\text { covered (effectively defeated by } \\
\text { amendment) }\end{array}$ \\
\hline & 30 parliamentary questions tabled & None reported \\
\hline \multirow[t]{3}{*}{ Queen Mum's } & 8 motions from 3 MSPs, 1 debated & $\begin{array}{l}\text { Only speech introducing the debate on } \\
\text { the motion reported }\end{array}$ \\
\hline & $\begin{array}{l}43 \text { written questions and } 2 \text { oral } \\
\text { questions tabled, one question at First } \\
\text { Minister's Questions }\end{array}$ & $\begin{array}{l}\text { One article mentioning questions, and } \\
\text { one on FMQs }\end{array}$ \\
\hline & $\begin{array}{l}\text { Private Members Bill proposed on } \\
\text { health board accountability }\end{array}$ & No coverage \\
\hline
\end{tabular}

Table 2: Coverage of parliamentary activity on campaign issues

Journalists regarded constituency MPs and MSPs as powerless, and preferred to target ministerial decision-makers. However, government was portrayed as remote and unresponsive to the immediate wishes of 'the people', especially the UK government.

Two of the campaigns advocated changes to policy reserved to Westminster - The Herald's campaign opposing asylum and immigration policy, and the Daily Record's call for changes to firearms legislation. The Herald framed the UK parliament as unaccountable to Scottish voters, ignoring the continued mechanism of constituency representation via MPs, and called for support from the Scottish Executive. This view was also popular among letter-writers: "My understanding of devolution does not include the Scottish people and their media agreeing to stay silent about issues in Scotland that are administered by Westminster" (letter to the editor, HD 08/08/07). Of course, Westminster is no less accountable to Scottish voters after devolution than it was before, but devolution introduced a closer government that is more sensitive to pressure from the Scottish press and their readership than the UK government. Furthermore, one letter-writer expected the devolved government to mediate between the Scottish people and the Westminster government: "What Scots hoped was that their 
votes [for devolution] would bring them a new parliamentary set-up in which their official spokespeople, the executive, would truly represent and reflect their views" (letter to the editor, HD 11/08/03), reflecting The Herald's strategy. However, the Scottish Executive was preferred for its proximity rather than any distinction of formal accessibility.

The Daily Record's campaign for an airgun ban similarly blamed public cynicism on politicians' disregard for the newspaper's account of public preference. The paper's assessment of the newly reelected UK government's decision against one of its campaign objectives, an airgun ban, was that it demonstrated untrustworthiness.

What do they expect the public to do now they have ignored our wishes? This is precisely the kind of double dealing which turns voters off politicians. (Leader column, DR 09/06/05)

The newspaper's favourable representation of conventional politics was therefore contingent on a plebiscitary response, and the trustworthiness of politicians is explicitly defined by their willingness to take the policy decision deemed most popular by the newspaper.

On the devolved campaign issues, various mechanisms were made available to facilitate citizen access to decision-making. There were public consultations on the issues addressed by the Daily Record's Section 28 and anti-social behaviour campaigns and the Evening Times' hospital campaign. The Evening Times encouraged readers to participate directly, whilst the Daily Record (on anti-social behaviour) offered participation via the newspaper's letter's page, though the final report dismissed the responses as a product of the campaign rhetoric. All three ultimately presented public consultation as a referendum exercise.

The Evening Times criticised the Health Board for refusing to accept the newspaper's framing of the public consultation exercise as plebiscitary rather than participatory, rejecting the significance of reasons for the opinion asserted. They characterised the health board as "arrogant" (15 times) and "smug" (ET 13/11/03), and an MSP called them "high-handed" (Sandra White (SNP) quoted in ET 20/11/03) for explicitly prioritising clinical arguments over public feeling that a hospital closure is a 'bad thing'. Health board Planning Director Catriona Renfrew was quoted as saying: 
It's not a matter of how many million signatures you get. If people look at the material and say 'There's something you've missed,' then it will be considered. We want people to consider the issues with us and respond on that basis. (ET 27/10/03)

Though it merely restated the remit of public consultation (a remit acknowledged by the Health Reporter), this statement was described as an "astonishing outburst", and the article was headlined "Health board boss slammed for insult to readers who sign petition to save the Queen Mum's". This discourse of personal offence continued, including two further uses of "insult", and a "slap in the face" (MSP quoted in ET 16/01/04), that the health board had "shown outrageous contempt for public opinion" (ET 17/02/04) and "poured scorn on the outcry" (ET 20/02/04). As a result, the newspaper blamed the health board for losing the public's trust (13 times), and creating cynicism (four times) by refusing to give in to pressure.

The Daily Record's Section 28 campaign similarly called for a plebiscitary response, but was also selective about which consultation responses constituted 'public opinion', excluding politically active citizens such as members of civil society organisations as sectional interests. The Daily Record rejected the Executive's claim that the consultation offered parents an opportunity to express a view, because First Minister Donald Dewar "refuses to be bound by the results - overwhelmingly against scrapping $28 \ldots$ so what was the point of the "consultation process"?" (opinion column, DR 17/01/00), without making it clear that this referred only to the views of the parents who responded, whilst the overall result was $70 \%$ in favour. However, the response was characterised as "Dewar comes under fire for refusing to guarantee he will accept public opinion on the issue".

The Evening Times did, however make good use of the Petitions Committee, at the suggestion of an ex-MSP campaigner who was involved in the launch of the campaign, but the main focus in the coverage was on the presentation of the petition to the Health Minister as a media event rather than formal due process, on the insistence of the Health Reporter. He believed that this was tactically more significant because "the Petitions Committee can't actually do anything at the end of the day" (John McCann). These approaches to public accessibility represent an ambivalent attitude that is consistent with the general lack of faith in parliamentary procedures. It also indicates that the representations of these mechanisms tend to suggest that citizens still need the newspapers to mediate access. 
Journalists, then, did not see their job as to inform voter choice (so that citizens could effect change at the allotted opportunity within the next five years), but neither did they facilitate direct engagement with systems of parliamentary access. Instead they saw their role as to effect immediate change on the basis that they were mediating popular, extra-parliamentary demands.

To substantiate this claim, the newspapers led various protest activities, attracting significant support from readers in the form of a petition (the Evening Times), a protest march (the Daily Record drugs campaign) and letters to the editor (The Herald). However, in the popular newspapers, support was framed as simply lending numerical weight to the newspaper's demands in a plebiscitary relationship (see also Birks, 2010a). In contrast, The Herald did make room for discursive contributions from the audience, including criticisms of the campaign, and also acknowledged the role of civil society campaigners (though they were often framed as "experts"), but journalists at the paper shared with those at the tabloids a definition of legitimate publics as an aggregate of (affected) individuals, not politically organised citizens, whilst struggling to portray themselves as plebiscitary leaders of popular opinion on asylum (see Birks, 2010b for further details).

The redemptive rhetoric was at least in part intended to communicate a brand-values message to readers, "to show that you are for your readers, that you are their champion, their friend" (David Leask, Chief Reporter, Evening Times). However, whilst Leask argued that this message was not entirely dependent on delivering the campaign objective, most journalists emphasised the central importance of winning. As Calum MacDonald, Deputy News Editor of The Herald said, "The old adage in newspapers that you should never start a campaign until you already know you've won", a received wisdom reported in very similar terms by all of the Daily Record journalists, and several others at The Herald and Evening Times, and attributed by Paul Sinclair (Political Editor, Daily Record) to the "increasingly commercial" nature of news. This can have the effect of compromising the campaigns' oppositional stance.

Both tabloid newspapers presented themselves as political outsiders opposing the remote establishment, but tended to focus blame on criminal perpetrators (the Daily Record on drugs, loan sharks and anti-social behaviour), and their criticisms on Westminster politicians (the Daily Record on airguns) or quangos (the Evening Times) rather than on the Scottish Executive, whose ministers they sought to influence. The Evening Times quietly accepted a compromise, the triple-location of 
maternity, adult and neo-natal services and the removal of the health board from the decision-making process, but publicly trumpeted this pragmatic outcome as a redemptive victory for "people power" (ET 30/09/04), despite the decision eventually resulting in the closure of the Queen Mother's and the relocation of the children's hospital.

According to ministers, senior journalists would even negotiate with them behind the scenes before embarking on a campaign; "I would hope that by the time somebody's got to the stage of doing a campaign on something that was in my patch I would already be talking to people, and looking to see how we could build some consensus around it" (Cathy Jamieson, Minister for Justice 2003-2007), what Malcolm Chisholm called "quite a positive partnership, I suppose mainly with the tabloid press and politicians" (Minister for Health and Community Care 2001-2004). As Justice Minister, Jamieson would typically negotiate with the Daily Record and the Scottish Sun to avoid "critical" campaigning, and in return the newspapers would seek support to make them look influential. Daily Record journalists listed various campaigns that did not run or would not be considered because ministers advised that they would not win, including restoring the earnings link to pensions (Sinclair) and anything on the NHS or social housing (Mark McGivern, Reporter). Furthermore, the Record's campaign in support of the executive's anti-social behaviour proposals was initiated at the invitation of ministers. This rather undermines the tabloids' claims to be oppositional outsiders fearlessly pursuing the demands of the people, and reveals them engaging in the kind of pragmatic politics they publicly criticise.

The exceptions were the Daily Record's Section 28 campaign and The Herald's asylum detention campaign - both fiercely critical of executive decision-making, but from ideologically opposite standpoints. Ministers were reluctant to discuss Section 28, insisting that the newspaper, society and parliament had all "moved on" since then (Jamieson), but they explicitly criticised The Herald for its oppositional tactics, since "if you answer you're likely to have it used against you, if you don't answer you're likely to be exposed as not having answered, and actually if you think the answer's a bit more complicated than a yes or no answer, there is no opportunity" (Jamieson), and similarly "I always felt that they never gave us an opportunity to try and communicate some of the other complexities about it” (Margaret Curran, Minister for Social Justice / Communities 2002-2004). Daily Record journalists argued that the newspaper's less publicly critical approach to the Labour-LibDem Scottish Executive made it more influential, whilst "the Tories and the Nats [SNP] are always saying they don't get a 
decent deal with us, that we give them stick all the time" (Dave King, Political Reporter), illustrating the lack of public discursive substance to either extreme in press-politician relationships, whether campaigns are privately agreed or a public stalemate of non-cooperation.

All three newspapers took a populist stance in as far as they not only discounted mechanisms of constituency representation and parliamentary debate, but also demanded a plebiscitary response from the government, including through those mechanisms designed to close the legitimacy gap in which populism thrives. However, The Herald did give some acknowledgement of the role of civil society associations in extra-parliamentary activity, whilst the popular newspapers portrayed themselves as essential intermediaries between the people and government. Furthermore, despite the redemptive rhetoric, in practice the commercial brand-building imperative meant that campaigns were more likely to privately negotiate and cooperate with government ministers in a manner that they would publicly criticise in politicians as pragmatic and strategically manoeuvring. Again, The Herald's progressive asylum detention campaign was an exception that remained genuinely oppositional, but also the Daily Record's Section 28 campaign, from the opposite ideological perspective. Where these two campaigns differed, however, was on the public interest justification for that dissent in terms of the moral outrage engendered in the public.

\section{Political legitimacy: personal authenticity and the moral authority of the victim}

This section will examine the ways in which the campaigns attempted to mobilize popular support or construct consensus through appeals to public interest notions of wrongdoing and injustice, with particular focus on the groups affected by the issues. It will also analyse the representation of politicians and public officials in terms of their response to those affected, including the moral sentiments associated with consideration of the sensibilities of others, and the definition of politicians' personal authenticity as submitting to the moral legitimacy and authority of the victim and their feelings.

The Evening Times chose to campaign on the maternity hospital closure for the very reason that it potentially affected everyone in the area, and would therefore have a universal appeal through instrumental self-interest. However, this was largely based on a similar instinct that they attributed to the public. 
And I think in the early days the feeling was 'this is a bad thing', and that the public see it as a bad thing, and we tend to agree with them on that. Without being entirely sure.... It's a bad thing, it just is, it'll be unpopular, it's just... doesn't seem right. (John McCann, Health Reporter, Evening Times)

Journalists soon found themselves faced with unexpected divisions of interest. First, they negotiated a potential conflict with the staff and patients of the other city maternity unit under threat of closure by arguing against the need to close either (for which they drew little expert support due to a low birth rate and shortage of consultants to staff all three units). Second, they faced the argument that the Queen Mother's was not properly equipped to treat women who suffered complications such as preeclampsia, putting their lives in danger. This was countered by a great deal of focus on the "link" (147 times) with the (unthreatened) neighbouring children's hospital, arguing that the proximity to neo-natal services saved the lives of dangerously ill babies who could otherwise die en-route from the further maternity hospitals.

\begin{tabular}{|c|c|c|}
\hline Table 3: Injustice in Evening Times & $n$ & $\begin{array}{c}\text { \% total } \\
\text { "risk" }\end{array}$ \\
\hline "Risk" & 84 & \\
\hline Risk to babies & 47 & $56.0 \%$ \\
\hline Risk to babies as a direct result of closure & 30 & $35.7 \%$ \\
\hline Risk to mothers & 17 & $20.2 \%$ \\
\hline Acknowledgement of risk to mothers & 2 & $2.4 \%$ \\
\hline Denial of risk to mothers & 2 & $2.4 \%$ \\
\hline Increased risk to mothers with closure & 5 & $6.0 \%$ \\
\hline
\end{tabular}

The focus on the children's hospital united the interests of the whole city, and provided a wealth of heart-rending case studies, but less than half (16 of 33) of the personal stories of parents' experience of the service were directly relevant to the link between the hospitals and almost a third (10) were entirely unrelated to the maternity hospital. The campaign therefore rested chiefly on an assumption of instinctive public opposition to a hospital closure and the expected failure of the political system to respond to it, however, despite the use of emotional testimonials, the newspaper struggled to coherently establish the proposal as an injustice.

The political legitimacy of the campaign's objective therefore rested on the conflation of opposition to the closure with 'caring' - demonstrating personal authenticity. Journalists argued that the campaign 
was about "getting the officials in a position where they care about, or they're advised to care about doing something about it” (John McCann), without acknowledging that a professional judgement on the best clinical decision does not preclude caring about the outcome for patients. Accordingly, the Health Board were described as "bureaucrats" (seven times) - which was equated with an unhealthy obsession with money ("bureaucrats and bean counters", ET 09/10/03), and framed in somewhat dehumanising terms ("faceless bureaucrats", ET 30/09/04), whilst the Health Minister had "showed he really cared" (headline ET 01/10/04). One of the main reporters on the campaign argued that the experience of those affected was more authentic and meaningful than the dry clinical arguments.

It's a very famous anecdote that Malcolm Chisholm had visited the Queen Mum's across that bridge and met a mum from America, who'd come from America to have her child there, who was seriously ill. And he saw the child, the child recovered. [...] But he saw that, the baby and he went 'oh right', so even for him, a very clever man who was quite capable of understanding all the clinical arguments, even for him the simple human story told it better. (David Leask, Chief Reporter, Evening Times)

Malcolm Chisholm gave an account, in contrast, that focused primarily on the clinical evidence, and claimed that without an alternative solution he would have been prepared to "take the hit" from the media.

The Daily Record's Section 28 campaign was even more difficult to frame as public interest as opposed to public preference. The newspaper attempted to construct parents as the victims of the repeal as it constrained their freedom to reproduce their own views in their children. The newspaper avoided overtly depicting homosexuals as a threat, and instead portrayed middle class liberals as the threat to "ordinary" parents who wanted their children to be "protected from exposure to liberal views on homosexuality that may go much further than their own" (DR 21/01/00). This suggests a division among 'the people', not just between 'the people' and politicians. The millionaire businessman Brian Souter involved in financing the Section 28 campaign framed this as a class issue: "We do not want guidelines from a group of middle-class intellectuals who thought up these ideas in a trendy wine bar" (quoted in DR 25/01/00). The middle classes were referred to as the "chattering classes", or the "politically correct classes" (DR 19/01/00), in a discourse of a 'liberal elite' that suggests that values of human rights and equality are the new hegemony, whereby progressive values are reproduced through socialisation in institutions such as schools ${ }^{5}$. 
In contrast to the negative morals of condemnation associated with the Record's moral panic (implicitly, fear of children being 'turned' gay), the positive moral principles of democratic norms of tolerance and respect are portrayed as artificially imposed and socially or culturally elitist. Politicians' position on the issue was therefore constructed as wrongdoing on the basis of being perceived as "patronising" and "dismissive"; the paper warned then First Minister Donald Dewar, "To say he recognises the concern of parents, but does not believe it to be justified, is dangerous talk" (DR 17/01/00), and told readers explicitly that ministers "think they know better than you do" (DR 19/01/00). Later this was repeatedly described as "arrogant", "an insult", and "patronising". The Executive's dismissal of the campaign's quasi-referendum result was reported as "Wendy [Alexander]'s two fingers to the lot of you" and a "snub to 1million Scots" (DR 31/05/00).

In contrast, the Daily Record's later campaigns advocated on behalf of deprived communities in Scotland who suffer the effects of drugs, loan sharks and anti-social bahaviour. Here there is a clear public interest established in terms of the suffering of affected individuals, and an expectation of rousing moral indignation on their behalf. This can be usefully compared with the framing of The Herald's asylum detention campaign.

\begin{tabular}{|c|c|c|c|c|}
\hline $\begin{array}{l}\text { Table 4: Injustice in Daily Record and } \\
\text { Herald }\end{array}$ & Drugs & Loan sharks & $\begin{array}{l}\text { Anti-social } \\
\text { behaviour }\end{array}$ & Dungavel \\
\hline "Tragedy" & 29 & & & \\
\hline "Devastating" & 24 & & & \\
\hline "Lives" "ruined" & 11 & & & \\
\hline "Damaged" & 10 & & & \\
\hline "Misery" & 34 & 17 & & \\
\hline "Despair" & & 3 & & \\
\hline "At risk" / "easy prey" / "no choice" & & 8 & & \\
\hline "Trapped" / "enslaved" / no "escape" & & 15 & & \\
\hline "Vulnerable" & & 15 & & 3 \\
\hline "Fear" / associated adjectives & & 11 & 15 & 33 \\
\hline Tearfulness (“cry* / weep* etc) & & & & 18 \\
\hline "Innocent" & & & & 25 \\
\hline "Ordinary" / "decent" / "hard-working" / & & & 27 & \\
\hline "law-abiding" people / families & & & & \\
\hline
\end{tabular}


The four campaigns gave an account of the effects of issues on those affected, in a way that journalists at both papers understood as making the issues more compelling and significant to readers, using emotional appeals to connect with those values that take a structuring role in such stories. However, both newspapers also anticipated some resistance to these appeals to empathy for those affected, and therefore constructed them as passive victims to avoid victim precipitation explanations of having brought their suffering on themselves. The drugs campaign portrayed addicts as having been acted on rather than exercised agency in taking drugs (with drug dealers and even drugs themselves as the agents) - as being "damaged" and having had their "lives ruined" by drugs. The loan sharks campaign more explicitly constructed debtors as being "vulnerable" and having "no choice" but to turn to the loan sharks, and then being "trapped" by them, whilst the anti-social behaviour campaign distinguished the 'deserving poor' as "ordinary", "decent", "hard-working", and "law-abiding". The Herald's Dungavel campaign also represented asylum-seeking children as "vulnerable" and "innocent" of any crime or blame (21 times, in comparison with just twice in relation to the parents), though on the basis of being children rather than being asylum seekers, and therefore with an emphasis on how frightening they found the dawn raids and detention process.

Daily Record Political Editor, Paul Sinclair argued that the paper's impulse to "pull around the family" of victims was a positive and progressive appeal to human universals, aiming to use emotional empathy to prompt community feeling rather than fear - to produce an 'us' of mutual social responsibility without recourse to a 'them' who can be blamed. However, the Daily Record also focused on the criminal element as "evil" as well as 'objectively' wrong in law, leading to a lawenforcement angle.

\begin{tabular}{|c|c|c|c|}
\hline Table 5: Wrongdoing in the Daily Record & Drugs & $\begin{array}{l}\text { Anti-social } \\
\text { behaviour }\end{array}$ & Loan sharks \\
\hline "Evil" & 80 & & 11 \\
\hline "Scum" / "scumbag" & 11 & & 5 \\
\hline "Vile" & 3 & 4 & \\
\hline "Sickening" / "cruel" / "soulless" & 3 & & 1 \\
\hline "Prey & 7 & & 14 \\
\hline "Parasite(s)" / "bloodsucker(s)" / "leech(es)" & & & 19 \\
\hline "Ned(s)" / "yob(s)" / hooligan(s)" & & 84 & \\
\hline "Out of control" / "no respect" / "lawless" & & 8 & \\
\hline
\end{tabular}


The emphasis on this more obvious moral panic angle was clear in the ways in which the drugs campaign actively resisted any engagement with arguments over effectiveness of prohibition policies, asserting, "The case for the campaign against hard drugs is irrefutable. It is so obvious it does not even have to be stated" (leader column, DR 03/03/01).

The conflation of moral outrage at the problem with a "tough" law enforcement policy solution was such that disagreement was framed as causing offence. The only politician who was willing to argue that prohibition causes more harm to users than the intrinsic qualities of the drugs ${ }^{6}$ was then Scottish Socialist Party (SSP) leader Tommy Sheridan. Not only was he judged to be "out of touch", since "[t]he whole of Scotland has thrown its weight behind our campaign" (DR 03/03/01), but this disagreement was "egoistic" and "arrogant". As well as patronising the 'the people', he was accused of offending the feelings of victims with his arguments on policy, which were deemed "insensitive", "uncaring", "heartless", "disrespectful, mean-spirited" and giving "a two-fingered insult to the victims of drugs and their families" (DR 03/03/01) and as being "roundly condemned", and "attacked" by "families of dead addicts" (DR 10/03/01). The political objectives of the protest march were also tied up with the expression of victims' feelings; Gaille McCann of community organisation Mothers Against Drugs was quoted demanding "will he not acknowledge that this [the march] is an opportunity for parents to grieve together?" (DR 03/03/01). These criticisms suggest that the political objectives could not be challenged because they could not be separated from the personal feelings experienced by bereaved parents, so to criticise one was to offend the other. Once again, therefore, the response to any reasoned disagreement on effective solutions to the problem was to frame it as arrogant and insulting.

Neither were Scottish ministers were above using this rhetoric to promote their own policies, as one senior Herald journalist observed of the anti-social behaviour legislation, "I mean [then Communities Minister] Margaret Curran's defence of the entire bill is that this is a problem and it affects people" (Lucy Adams, Home Affairs Correspondent, The Herald), and the Daily Record's campaign followed that framing very closely.

'Cause it was at a time when the anti-social behaviour stuff wasn't that popular, and there was an argument that, folk said 'well it's not really necessary, blah blah blah'. [...] But if you were living in communities where these kids were hanging about outside your door every night of the week, they were saying, 'we want it', and Labour were saying that there was grounds for it because people in the community want it. And I think the reaction we got from our campaign 
showed that it was in certain areas, and it was there that it was the most effective, that there was a need for something to stop it. (Dave King, Political Reporter, Daily Record)

King refers interchangeably to people's experience of the problem, desire for the problem to be 'stopped' and 'wanting' the legislation. Whilst Curran made an impassioned defence of the argument that politicians had not been fully aware of how profoundly this kind of social disorder affected disadvantaged communities, or just considered it inevitable in deprived areas of the city, and that "nobody had been listening to them", there is a difference between being motivated by moral sentiment to act to improve people's circumstances, and accusing those who question the effectiveness or fairness of those actions of not caring about the victims.

Although the Daily Record's airguns campaign did not personalise the issue to the same degree either in terms of victims or perpetrators, opposition to an airgun ban was similarly interpreted as lack of sympathy and even disrespect for the parents of the two year-old child who died. When Michael Howard, then Conservative leader, questioned the efficacy of a ban in a radio interview, it was framed as having "sparked fury" and "caused further distress" to the "grieving" mother, who "accused Howard of laughing at her" (DR 19/03/05). An anti-gun campaigner also described Howard as "a cold man", and his opposition to an airgun ban "offensive" (DR 19/03/05).

The Herald avoided such moral judgements of blame and offence; whilst "racism" was raised (four times, twice in letters) as a moral evil attributed to opponents, anti-racism was not universalised as common sense in the same way as being "against drugs" was in the Daily Record, and indeed it was occasionally acknowledged that racist and anti-immigration views are common. The Herald's discourse of uncaring officials was largely contributed by letter-writers, who bemoaned the "callousness of uncaring officialdom" (HD 07/08/03) - echoed in an opinion columnist's criticisms of "officialdom washing its collective hands" of the problem - and argued they had ceased to be "decent and humane", had "cast away basic drives of care and kindness" and "slough[ed] off thoughtful emotion" (letters to the editor, HD 07/08/03) giving accounts of other-orientation as a human instinct and a moral sentiment, but using it to attribute blame. Journalists avoided direct personal insults, however, and rather implied emotional remoteness through their focus on ministers' "silence" (54 times). This simply demands that the politicians take some action to tackle the suffering, without closing down the debate on solutions, yet without engaging with that debate either. 
However, whilst the campaign avoided the populist discourses of righteous moral outrage against 'evil', all of The Herald journalists expressed some disquiet about the campaign (which was driven by the editor), either because it was too populist or not populist enough. The focus on the emotional effects on children was seen as a valid way to make the story meaningful to the audience, but limiting if it becomes too central to the story.

You need to illustrate the human side to things, and there's a human aspect to every story, you know $[\ldots]$ I mean to say, things are often presented in the abstract and it's a journalist's job to actually pin that down and say, 'right what this means is asylum seekers getting dragged into detention centres at gunpoint', you know, all these kinds of stories. There's a kind of personal aspect that I think is the right thing to highlight, and there's an inherent danger, I think given the trend of the last few decades, to emphasise the personal at the cost of the political, which is just a case of pushing it too far. I think that's a consequence of tabloidisation of news and I think in a sense we've succumbed to that, not altogether, but there was an aspect of that, in the Dungavel campaign. (Damien Henderson, Reporter, The Herald)

This was reflected in some of the correspondence on the letters to the editor page, which argued that the emotive personalisation of the story was manipulative and an impediment to a rational response. One protested that "I feel we have been subjected to a great deal of emotional blackmail here", based on the photogenic quality of the Ay children; another criticised the family's final press conference as "a shameless pulling of every emotional stop", and viewed this sort of rhetoric as unhelpful in making rational decisions - "an example of hard cases making bad law" (letter to the editor, HD 06/08/03). It could certainly be argued that the campaign gave too little attention to the systemic failures of asylum policy and administration, or the potential alternatives to detention for families awaiting deportation, and that the emotional focus was a strategy for avoiding dealing with this potential controversy.

For some, the topic as a whole was not sufficiently populist, and the emphasis on moral sentiment was in itself alienating to the audience; Deputy News Editor Calum MacDonald argued that "sometimes it can be very posturing and very kind of pose-y and 'aren't we smart'". The more common view, however, was that the principle was sound but the 'victims' were not sufficiently sympathetic and 'deserving', and failed to support the appeal to moral sentiment. In particular, the Ay family were seen as undeserving because they were not technically eligible to apply for asylum (as 'third country 
applicants) and had actively resisted the system by launching a series of appeals and absconding to avoid deportation following a previous appeal.

We were using them for political ends, and there's always an aspect of that, let's not be naive about that, but their case was not strong enough to do what The Herald wanted to do with them [...] and I think readers felt patronised by that. (Damien Henderson, Reporter, The Herald)

The formal rationality of existing immigration laws - the technical and the pragmatic - were deemed more popular than the affective, or even substantive rationality of human dignity and rights. Interestingly, this argument is not dissimilar from the tabloid construction of 'deserving' victims as passive and helpless, not as fighting against systemic injustice.

The framing of issues in terms of how they emotionally affect people was used, in principle, to inspire empathy and an internalisation of the other in personal conscience through an appeal to human universals', especially protection of the vulnerable. Rather than an oppressive exertion of patronising moral authority, this aims to inspire civilised moral sentiment. However, the discourse of the most populist aspects of the Evening Times and Daily Record campaigns reversed this distinction; moral condemnation was portrayed as of the people and any dissent from that view as elitist and offensive, whilst the democratic principles of tolerance and equality were seen as being imposed by an elite and dissent from them as the defence of community values. Moreover, such universals were used by all of the campaigns in place of a reasoned or objective basis for public interest justification, and used to back up an instinctive or common sense assertion of consensus. This misuse of victims as a symbol of moral legitimacy and authority was also used by the tabloid campaigns to question the legitimacy of opponents and insist on populist policy responses from politicians, and by The Herald simply to avoid dealing with the controversy surrounding the asylum system.

\section{Conclusion}

The campaigns examined here illustrate the delicate line between political protest and political populism: between mobilisation and plebiscitary rhetoric, between moral principles in the public interest and hegemonic moral panics, and between moral sentiment and emotional blackmail. Where the campaigns tended more to the latter than the former it was broadly for the strategic purpose of 
securing a response that could be presented as a plebiscitary victory, which was regarded as dependent on the construction of consensus through emotional appeals.

Conventional politics was not portrayed as any more accessible in Scotland, since it was the executive branch that was targeted, whilst the mechanisms of accessibility are located - like constituency representation - in the parliament. Although parliament has greater scrutiny over the executive in Scotland, constituency and regional MSPs were still considered powerless, as were the committees, including the Petitions Committee. The legitimacy gap was portrayed in much the same way, then, as in the national or English local press. However, the rhetoric of redemptive direct (plebiscitary) democracy was not matched by the campaign practice, which was predominantly strategic and pragmatic in securing a guarantee of apparent influence through private negotiation.

The campaigns did, however, attempt to engage citizens in the politics of protest, in particular by making the issues meaningful to them through exploration of the ways in which they affect people, and by calling on readers to express their outrage. To some extent this engages the moral sentiments associated with civility and civil society - tolerance, kindness and sympathy for others - but the tabloid campaigns tended to rely on vilification of 'the other' to construct an easier consensus against those who could be blamed for social 'evils'. Furthermore, explicit appeals to moral sentiment was often avoided or resisted as it was viewed as patronising (and less commonly, constructed as a presumably ineffective - liberal hegemony) and therefore more likely to produce resistance than supportive consensus behind the campaign.

Therefore a discourse of authenticity of feeling was used to legitimise demands for a plebiscitary response to popular or 'victim' preference, even in the absence of principled public interest or evidence for the effectiveness of the policy advocated. The tabloid campaigns employed populist strategies of discrediting political opponents as remote, patronising or uncaring in order to close down debate, framed by a discourse of offence, but even The Herald sought to avoid divisive controversy by focusing on the emotional impact of victims, although journalists at the newspaper recognised that this was problematic.

The populist impulse reflects journalists' assumptions that public engagement in political issues is contingent on constructing an artificial sense of community through an 'us and them' mentality, and on 
the direct and immediate effectiveness of the protest. Further research is necessary to assess how accurate journalists' assumptions about their audience are, but certainly civility is a "cool concept" (Bryant, 1995: 145) in contrast to more exclusive ethnic or communal attachments, and therefore more difficult to arouse in citizens. That is not to say, however, that there is no potential for the democratic engagement of civil society via the press, as The Herald's campaign begins to indicate. However, the campaign's shortcomings, in terms of the use of emotional framing to avoid debate on the asylum system, also suggest that the journalistic conventions and market pressures that lead to the avoidance of controversy constrain the legitimate politics of protest in the press.

\section{Notes}

${ }^{1}$ For obvious reasons to do with advertising income and legal resources, the press are far less likely to be critical of powerful commercial interests.

2. In fact, editors argue, in rather circular logic, that newspapers' political influence is both justified by and the cause of readers' trust, (Birks, 2010b).

3. Although Canovan was discussing politicians specifically (in what she termed 'politicians' populism) this is the form that is most relevant to protest leaders.

4. This is particularly attributed to the local press (Franklin, 1997), though it has also been noted that their past coverage of local politics, though more extensive, was largely uncritical (Murphy, 1976, Temple, 2005).

5. Of course this misrepresents both the middle and working classes, assuming the absence of bourgeois middle class institutions still reproducing values that defend their own interests and working class associations of civil society that engage in counterhegemony.

6. In terms of drugs cut with dangerous chemicals and of unpredictable strength, as well as escalation to harder drugs through exposure to drug dealers.

\section{References}

Aldridge, M. (2003) The ties that divide: regional press campaigns, community and populism. Media Culture \& Society 25(4): 491-509.

Barr, R. R. (2009) Populists, outsiders and anti-establishment politics. Party Politics 15(1): 29-48.

Birks, J. (2010a) Press protest and publics: The agency of publics in newspaper campaigns.

Discourse \& Communication 4(1): 51-67. 
Birks, J. (2010b) The democratic role of campaign journalism: partisan representation and public participation. Journalism Practice 4(2): 208-23.

Blair, T. (2007) Public Life. Speech to Reuters. London, 12 June.

Blumler, J. G. and Kavanagh, D. (1999) The third age of political communication: influences and features. Political Communication 16(3): 209 - 30

Branigan, T. (2005) Jowell warns of voter cynicism. The Guardian, 17 January, http://www.guardian.co.uk/politics/2005/jan/17/uk.voterapathy, accessed 6 February 2005.

Bromley, M. (2005) Subterfuge as public service: investigative journalism as idealized journalism. In: S. Allan (ed.) Journalism: Critical Issues. Maidenhead: Open University Press, pp. 313-27.

Bryant, C. G. A. (1995) Civic nation, civil society, civil religion. In: J. A. Hall (ed.) Civil Society: Theory, History, Comparison. Cambridge: Polity Press, pp. 136-57.

Canovan, M. (1981) Populism. New York and London: Harcourt.

Canovan, M. (1999) Trust the people! Populism and the two faces of democracy. Political Studies $47(1): 2-16$.

Cohen, J. L. and Arato, A. (1992) Civil Society and Political Theory. Cambridge, Mass.: The MIT Press.

Conboy, M. (2002) The Press and Popular Culture. London: Sage.

Corner, J. (2003) Mediated persona and political culture. In: J. Corner and D. Pels (eds.) Media and the Restyling of Politics: Consumerism, Celebrity and Cynicism. London: Sage, pp. 67-84.

Cottle, S. (2008) Reporting demonstrations: the changing media politics of dissent. Media, Culture \& Society 30(6): 853-72.

Ettema, J. and Glasser, T. L. (1998) Custodians of Conscience. New York: Columbia University Press.

Franklin, B. (1997) Newszak and News Media. London: Hodder Arnold.

Habermas, J. (1996) Between Facts and Norms: Contributions to a Discourse Theory of Law and Democracy. Cambridge, Mass.: MIT Press.

Higgins, M. (2008) Media and Their Publics. Maidenhead: Open University Press.

Hollingsworth, M. (1986) The Press and Political Dissent: A Question of Censorship. London: Pluto Press.

Joyce, P. (2002) The Politics of Protest: Extra-Parliamentary Politics in Britain since 1970. Basingstoke: Palgrave MacMillan.

Langer, A. I. (2007) A historical exploration of the personalisation of politics in the print media: the British Prime Ministers (1945-1999). Parliamentary Affairs 60(3): 371-87. 
Lippmann, W. (1993 [1927]) The Phantom Public. New Brunswick, London: Transaction Publishers.

Lloyd, J. (2004) What the Media are Doing to Our Politics. London: Constable.

Lupton, M. (2006) In our backyard, yes please. The Guardian, 9 January, http://www.guardian.co.uk/media/2006/jan/09/pressandpublishing.asylum, accessed 3 December 2007

Lynch, P. (2001) Scottish Government and Politics: An Introduction. Edinburgh: Edinburgh University Press.

McCrone, D. (2002) Marking the Card: The Scottish Parliament at 1000 Days. Paper presented at the conference on 'Renovation or Revolution? New Territorial Poltiics in Ireland and the United Kingdom', at the Institute for British-Irish Studies; 3rd April, University College Dublin, ROI.

Milne, K. (2005) Manufacturing Dissent: Single Issue Protest, the Public and the Press. London: Demos.

Murphy, D. (1976) The Silent Watchdog: the Press in Local Politics. London: Constable.

Philo, G. (2007) Can discourse analysis successfully explain the content of media and journalistic practice? Journalism Studies 8(2): 175-96.

Schlesinger, P., Miller, D. and Dinan, W. (2001) Open Scotland?: Journalists, Spin Doctors and Lobbyists. Edinburgh: Polygon at Edinburgh.

Scottish Executive (2004) Consultation Good Practice Guidance. Edinburgh: Scottish Executive.

Seligman, A. B. (1995) Animadversions upon civil society and civic virtue in the last decade of the twentieth century. In: J. A. Hall (eds.) Civil Society: Theory, History, Comparison. Cambridge: Polity Press, pp. 200-23.

Sunstein, C. (2003) Why Societies Need Dissent. Cambridge, Mass.: Harvard University Press.

Temple, M. (2005) Carry on campaigning: the case for 'dumbing down' in the fight against local electoral apathy. Local Government Studies 31(4): 415-31.

Temple, M. (2006) Dumbing down is good for you. British Politics 1(2): 257-73.

Word count: 10,663

Date: $16^{\text {th }}$ March 2011 